\title{
ResearchGate
}

See discussions, stats, and author profiles for this publication at:

https://www.researchgate.net/publication/243509836

\section{Aesthetics of Blankness: Political Imagination in Marguerite Duras's Hybrid Narratives}

Article in Romanic Review · May 2010

$\begin{array}{ll}\text { CITATIONS } & \text { READS } \\ 3 & 185\end{array}$

1 author:

Daniel Just

Bilkent University

22 PUBLICATIONS 25 CITATIONS

SEE PROFILE 


\section{AESTHETICS OF BLANKNESS: POLITICAL IMAGINATION IN MARGUERITE DURAS'S HYBRID NARRATIVES}

Il y aurait une écriture du non-écrit. Un jour ça arrivera. Une écriture brève, sans grammaire, une écriture de mots seuls. Des mots sans grammaire de soutien. Égaré. Là, écrits. Et quittés aussitôt.

Marguerite Duras, Écrire

$I^{2}$

$\mathrm{n}$ an interview with Jacques Rivette and Jean Narboni from November 1969, 1 Marguerite Duras attributed the peculiar style of her new book Détruire, dit-elle to her distaste for novels. It was because of the way novels construct sentences, she argued-“à cause de phrases"—that she tried to destroy all conventional grammar and create a narrative that would be as free of style as possible ("Destruction" 45). This new anti-novelistic mode of writing that offered a more succinct and less stylistically indulgent storytelling, however, was not driven by personal aesthetic preferences. For Duras, the issue at stake was political. Suggesting that brevity was the only possible reaction to the demands raised by the changing role of art in society, Duras insisted that the fragmented and austere style of her new book, in its refusal to conform to the hectic pace of contemporary life and to the lack of time and patience of present-day readers, was a response to the political need for action. Considering Duras's involvement in the events of May 68, it is not hard to guess the origin of this idea. But the action she had in mind was quite unusual. It had little to do with providing people with shorter books and inspiring them to spend more time on political activities. It was much more a matter of an active role she wanted her readers to assume while reading her stories.

Duras's vision of a new type of ascetic literature does not immediately strike one as a politically charged form of art. Duras neither argues for a shift of emphasis from literature to politics (from reading to action), nor pleads that literature has a duty to communicate a clear message in an unequivocal language. Instead, she asks literature to turn against itself as a means of communicating meaning. Her argument proposes that the way we tell stories is never without political implications. Even when literature turns against itself-or precisely when it does-it remains committed because, by questioning the way we understand ourselves, it helps in shaping the future. In this unorthodox

The Romanic Review Volume 101 Number 3 @ The Trustees of Columbia University 
version of littérature engagée, Duras posits aphoristic writing as an artistic instrument that connects the realm of the aesthetic with that of the public and the political.

The question of whether literature should convey a clear meaning was nothing new at the time of Duras's interview for Les Cabiers du cinéma in 1969. It was widely discussed in French literary circles after Jean-Paul Sartre's Qu'est-ce que la littérature? (1947) and strongly influencing theories of literature in the fifties. Perhaps most importantly, Roland Barthes and Maurice Blanchot returned to Sartre's claims about committed literature, Barthes in Le Degré zéro de l'écriture (1953), and Blanchot in various texts starting with the 1948 anti-Sartrean rebuttal "La litterrature et le droit à la mort" and continuing with articles published in the early fifties and collected in 1955 in L'Espace littéraire. What for Sartre represented the strength of all prose literature, namely its power to convey meaning and thus its obligation to be "engaged," became for both Barthes and Blanchot-although in different ways-an obstacle with which literature is destined to constantly struggle. But the concreteness of meaning was not the only target of Barthes's and Blanchot's arguments. It was also the genre of the novel, and especially its way of depicting personhood as a self-enclosed, monadic type of subjectivity that Barthes and Blanchot contested. Not without resonances in Duras's own later statements about the social role of art, Blanchot presented a very anti-Sartrean definition of literature: the essence of literature is its disappearance and the nature of literary language its tendency toward its own destruction (265).

Literary biographers, as well as Duras's own critical texts and interviews, reveal that she was familiar with Blanchot's and Barthes's works already in the late fifties. What made her return to them after May 68 was their political potential. Destroying the novel, meaning, and the subject in a blank, fragmented, and exhausted narrative, Duras believed, held a potential for opening something entirely new. It was above all the destructive power of empty language-one that she called in a very Barthesian fashion "le point zéro" and "le point neutre" ("Destruction" 54) -that she referred to in order to support her argument that Détruire, dit-elle was a political book: a book about the destruction of power, knowledge, memory, judgment, but most of all, "la destruction de l'être personnel" (51). Against what one would intuitively expect, Duras suggested that the blankness of the story, coming as a result of destroying everything without offering anything in its place, did not reinforce a self-enclosed existence but was instead supposed to work toward its opening. If we accept Duras's all-embracing conception of the political for a moment, the political underpinning of Détruire, dit-elle appears as something more than just a violent destruction of meaning. Rather than in the destruction itself, the political dimension of this story is in its aspiration to maintain the 
resulting semantic void. The political, in other words, resides in the narrative language that sustains the emptiness even after everything has been swept away. Duras admitted that creating such a language was difficult, but added that her struggle, far from being a sign of despair over collapsing discourse, was an expression of hope (53). Not unlike the hope she felt during the May general strike ("Yeux" 39-42), she was now convinced that the truly new could come only by the utter exhaustion of the old. Paradoxically, it was not action but exhaustion that she proposed as a political and literary tool leading to a genuine action.

Readers of Détruire, dit-elle might wonder if Duras's political plan for a new aesthetic revealed in the interview with Rivette and Narboni was not carried out in an unseemly way. After all, fragmented syntax, exhausted atmosphere, and inhibited flow of narration are not the kind of devices that can easily initiate a more active readership. It is Duras's peculiar understanding of action that is perplexing and that, indeed, confused Rivette and Narboni as well. Without stating it explicitly, Duras imagined that what would result in action is not an encouragement of the reader's subjective agency while reading but exactly the opposite, namely the inhibition of the process of reading. The reader of Duras's story is not expected to act (either in the real world or by actively searching for textual meanings) in reaction to the penury of the narrative material. The reader's role is merely to enact literary destitution. This notion of action envisions it not as an immediate effect of reading-because this activity is made anything but easier-but as a delayed effect of the blankness of the story. A more active reader, one that is not reduced to a passive receptacle, emerges from material that is monotonous and tiresome. Duras maintains that such a stimulation of action via utmost exhaustion is a form of literary commitment. In her scenario, the writer, by destroying sentences and destabilizing characters, engages in making the readers undergo a similar devastation, thereby advancing something entirely new and unpredictable.

Even though Duras's early literary works have not been registered as overtly political, Duras was not new to politics at the time of the May 68 events. ${ }^{1}$ Starting as a member of la Résistance, she joined the PCF in 1944, only to

1. A notable exception in this regard is Jane Bradley Winston who has recently drawn attention to the political undertones in Duras's early work (without disregarding, it should be added, the part Duras took in controversial projects, such as assessing potential risks for the French investors in Indochina, while working at the Colonial Ministry before the war). 
resign in 1950 and become increasingly critical of the Communist Party's dogmas, its adherence to the Soviet dictate, and non-involvement in the process of decolonization. During the war in Algeria, Duras participated in founding the committee of intellectuals against the war, and in 1960 she joined the controversial "Manifesto of 121" that encouraged French soldiers in Algeria to disobey. In the last four years of the war, she wrote articles for FranceObservateur against racism in France, colonialism, police harassment of immigrants, as well as pieces about those she called "dispossessed" (the Algerians, Jews, foreigners, criminals, workers, children, mental patients, and later, in the 1970s and 1980s, women and homosexuals). Politically, as a journalist for France-Observateur and later Libération, she was a vocal speaker against both de Gaulle and the Communists: she wrote against the war in Algeria, the invasion of Hungary, the occupation of Czechoslovakia, and the repression of the solidarity movement in Poland. By 1968, Duras became increasingly critical of all power structures. In May, this political stance brought her to the "Comité d'Action étudiants-écrivains," which, for several months, organized meetings with students and writers, offering a platform for discussions and experiments in creating a radical form of communist collectivity. It is in these talks that one can locate the source of the ideas expressed in the interview with Rivette and Narboni. In the words of an anonymous text, "Mots de désordre," published as an outcome of one of the group's debates (and later attributed to Maurice Blanchot), what bound those who had attended the meetings was their "affirmative refusal." Duras echoed this demand to remain outside any programmatic scheme in her own, at the time also anonymous, contribution to the Committee, "Sur le comité d'action étudiants-écrivains." In this pamphlet, she repeated that no positive political program held the group together except refusal and depersonalization of its members, and that this depersonalization was the first step in the direction of a rigorous type of freedom ("Yeux" 71-82).

In the 1970s and 1980s, Duras continued with her politics of refusal, occasionally lending her voice to less indeterminate political agendas (the feminist movement, for instance, and the candidacy of François Mitterrand for French president). Even then, however, her momentary preferences did not overshadow her fundamental political convictions. Feminism, for example, with which she was associated most closely in the 1970s, was a movement she perceived as politically inadequate and thus only transitory. As the articles in Sorcières and interviews in Les Parleuses show, Duras wanted to empower women and allow them to open new, non-patriarchal modes of representation, but women's liberation and inclusion in public governance, she believed, could not be the ultimate goal. With the political ideal of a radical absence of power, Duras was afraid that giving women their identity and share of power would 
result in only small political changes and in perpetuation of other forms of exclusion (Duras and Gauthier 73).

Where could, then, Duras be placed politically, both in the late sixties and after? In 1968, she was a Communist with strong anarchist leanings. A few years later, in 1970, she reiterated her political plan of negating the existing order and replacing it with nothing, a stance that required a Communist "qui croit que communisme est impossible" (Ababn 94). In 1977, she still claimed to be a Communist-"Je suis communiste"-only to add, "Je vis un communisme bafoué, égorgé" ("Duras explique sa position politique"). Some of the anti-PCF statements in Duras's film released that year, Le Camion, show that she borrowed heavily from Dionys Mascolo's ideal of communism as a unity of radical political equality and ethical respect for absolute otherness (Camion 37). Ever since leaving the Party, Duras considered herself a Communist who was against partisanship and doctrinal loyalty. In 1977, this idiosyncratic version of communism with a preference for void and nothingness- "no state at all, an absence of power" ("Voie" 177)—did not sound much different from its 1969 version. Duras was, again, arguing that it was the fear of emptiness and our persistent need to give meaning to life that kept crippling our political choices. She insisted that only a total destruction of all structures and all operative notions through which the West has been perpetuating its values, and through which the dominant social groups reinforce their elite status-notions such as "identity" and the "subject"—can lead to a more egalitarian world (Vision).

With no political program and no practical considerations for reality and the kind of transformations it could possibly permit, Duras never offered a consistent politics. Due to her unique understanding of the political, it was not very difficult for critics and readers to divorce her politics from her literary works. Already in the fifties, Duras's narratives were introduced to the audience as romantic stories about love, youth, and human misery, an image strengthened by René Clément's 1958 film adaptation of Un Barrage contre le Pacifique and the ensuing circulation of her photographs next to the exotic pictures of colonies. All of this contributed to the trend of downplaying the political relevance of her subsequent works and the significance of her political interventions. Although Duras persistently fought this tendency to depoliticize her work by aligning herself with communism, her rhetoric of void and destruction suggested an idea of innocence and uncorrupted future that was contentious and that many saw as being of a very limited political use. Even the otherwise enthusiastic Leslie Hill admits that Duras's apocalyptic vision is naïve because it institutes an extrahistorical vantage point that "marks off the end of progressive history and embodies the possibility that the innocence and gaiety at the origin of time may be experienced anew" (38). And yet, it was precisely this vision that Duras defended, however inconsistent, impractical, 
and violently romantic it was. Even though she would slowly accept its unfeasibility for practical politics in the late eighties and early nineties, for the time being this political vision sustained her engagement in both art and politics.

When Duras talked about the joint destruction of the novel and the individual in November 1969, she admitted that Détruire, dit-elle was only a start, and that this destruction and creation of "textes hybrides" (Destruction 57) was more a project for the future. Although the seventies bore witness to her shift from prose to film and drama, Duras did not abandon this plan. In many of her works from this time--the "texte-théâtre" India Song (1973), for example, which was adapted to the screen in 1974 , the play L'Eden cinéma (1977), the improvised reading of a script in Le Camion (1977), and the series of film-narrative monologues Aurélia Steiner (1979) — the main ambition to experiment with generic hybridization and its potential to create new modes of storytelling remained. When Duras started publishing literary narratives again in the early eighties, her texts drew significantly on the experimentation she undertook in film and theater over the previous decade. Even a fleeting look at her early eighties works reveals unmistakable cross-generic similarities involving film, drama, and prose. Take, for instance, the film L'Homme atlantique (1982), the play Agatha (1981), and the hybrid genre of the "récit-théâtre" La Maladie de la mort (1982); or the film Agatha et les lectures illimitées (1981), the play Savannah Bay (1983), and the récit-théâtre L'Homme assis dans le couloir (1980). Even though these pieces fall into different genres, they are not only formally alike but express a relatively uniform subject matter that produces analogous effects. It comes as no surprise, then, that the material of L'Homme atlantique became a basis for a film and a récit-théâtre; that Duras turned her play Agatha into a film Agatha et les lectures illimitées; that La Maladie de la mort encouraged its dramatization in the appendix containing directions for staging; or that La Maladie de la mort and L'Homme assis dans le couloir were considered for film adaptations. Despite the powerful similarities that bind these works together, one can, indeed, find exceptions to this threadbare aesthetic (the Aurélia Steiner film series, for example, which, for all their austerity, were constructed around a set of metaphors relating to the Holocaust; or the play Savannab Bay that shows a similar emphasis on the metaphorical construction). But the only real anomaly was L'Amant (1984), which, with its écriture courante and explicit use of the first-person narrator identified with Duras, introduced elements that transcended the blank aesthetic and pushed it toward a less Spartan, and more commercially successful, artistic form.

The single most important common feature of Duras's works from the early eighties, and the central device in her project to de-novelize literary narratives, 
was the prominence of dialogue. Like in drama where dialogues do away with the need for narrator, in the early eighties Duras told a story in a dialogic mode, with only sporadic use of narrative voice. Since there was no narrator to survey the progress of the story, situate dialogues, and point in the direction leading to the resolution of narrative tensions, the stress fell entirely on the characters' utterances. One of the obvious effects of this all-encompassing dialogue was that the story lost its predictable direction. Even though this was not an unprecedented move in the history of narrative literature-its prototype in Romanic literatures can be found in Benito Pérez Galdós's novel Realidad (1892)-Duras introduced dialogues that did not try to substitute for the lost action. Since her characters remained mostly quiet, resting, sleeping, or waiting for the other person to talk, the dialogues they engaged in were anything but invigorating. With the narrative weight placed on oblique and repetitious verbal exchanges, which were, moreover, often interrupted with prolonged silences, what Duras's stories displayed was their hindered tempo and noneventfulness. As the following passages from La Maladie de la mort and Agatha show, the same low dramatic voltage emerged from two generically different yet stylistically almost indistinguishable texts:

Elle remue, les yeux s'entrouvent. Elle demande : Encore combien de nuits payées? Vous dites : Trois.

Elle demande : Vous n'avez jamais aimé une femme ? Vous dites que non, jamais.

Elle demande : Vous n'avez jamais désiré une femme ? Vous dites que non, jamais.

Elle demande : Pas une seule fois, pas un instant ? Vous dites que non, jamais.

Elle dit : Jamais ? Vous répétez : Jamais. (Maladie 34-35)

Pas de réponse.

LUI. - Il ne sera plus rien.

ELLE. - Non.

LUI. - Il ne sera plus ni vivant ni mort, il sera à moi de cette façon-là.

ELLE. - Oui, il est à vous.

Silence

LUI. - C'est ce que vous vouliez me faire.

ELLE. - Oui.

LUI. - Cette souffrance. 
ELLE. - Oui.

LUI. - Agatha, Agatha.

ELLE. - Oui. (Agatha 13)

Duras's early eighties hybrid stories were almost entirely composed of oneword exchanges, moments of silence, and simple questions that precipitated a series of short circular answers. Even though the often included stage directions provided some information about the settings, they were highly impersonal and with no narrative agency that would help to move the story into its next phase. The auxiliary dramatic mechanisms merely framed the dialogues and accentuated the sense of temporal immediacy. Rather than poetry-as the critics who have emphasized the poetic nature of Duras's stories and their preoccupation with the sublime have argued ${ }^{2}$ - the key to the stylistic and generic distinctiveness of these texts lies in drama and film. It was the bare aesthetic Duras discovered in her films and plays in the seventies that she tried to translate into literary narratives. In particular, she looked for narrative equivalents to the dramatic staging of dialogue and the cinematic use of stillframe images with their evocation of silence and emptiness. The underlying tenet of her experiments was, again, political. She wanted to see what the faltered language and the resulting linguistic void had to offer after the intimacy guaranteed by the narrative voice was removed and all that remained was an aesthetically blank material.

Even without considering their political motivation, Duras's dramatization of the story and inhibition of narrative progress pose a serious challenge to narrative theory. If prose is inherently metonymical because narratives advance by contiguity, with each clause taking its impetus from the previous one, Duras's récit-théatres undermine their own prosaic foundation because they suspend metonymy. Whenever this happens, as Roman Jakobson theorized in "Two Aspects of Language and Two Types of Aphasic Disturbances," the text moves to the opposite linguistic and literary pole, namely metaphor. According to Jakobson, all literary texts tend toward either one pole or the other. The text is either metonymic, as in prose (and the realist prose most of all), or has a strong metaphoric tendency, as in poetry (and the symbolist poetry above all). Although the two poles are extremes that never appear in a pure form in any literary work, Jakobson insists that the ratio of their mixture of metonymy and metaphor depends proportionately on their distance from one pole and proximity to the other. This schema, he adds, can explain linguistic

2. For the former see De Chalonge 186, n. 27; for the latter Alazet 1998 and 2001. 
disturbances as well: among the aphasics, the use of metonymy and synecdoche compensates for the inability to select words, and the use of metaphor for the inability to combine them (55-82). Challenged by literary theorists on a number of occasions since its formulation, Jakobson's chart, however, often proves one-dimensional. Its usefulness as a diagnostic tool applied to Duras's récit-théâtres is in the way in which these texts resist its logic. The problem with Duras's narratives is that they depart from metonymy, and thus prose, but do not get any closer to metaphor and poetry. They not only do not tend to one pole or the other; they also present us with something different than a combination of the two extremes. Retaining the smallest level of contiguity, these hybrid texts remain narratives, while their level of metaphoricity turns them not into poetry but into plays. Metonymic and metaphorical poles are not combined here but both reduced to a minimum. As a literary genre, the récit-théâtre, a generic hybrid of a récit and a play, is a type of narrative with almost no metonymy and almost no metaphor.

From the purely linguistic and rhetorical perspective, the peculiarity of the récit-théatre is in the brusque utterances, phraseologic repetitions, and sudden silences. Although critics remind us of Duras's multi-linguistic childhood and its influence on her style-Jean Cléder, for instance, argues that Duras's sentences appear formless to French speakers because they imitate Vietnamese syntax by placing important words at the end of sentences (68)-the use of parataxis in Duras's works decreases with time. Considering the dominance of typographically isolated monosyllabic expressions, such as "Ah," "Oui," and "Non," in her later work, what seems to be a more direct inspiration for the stylistic oddities of the récit-théatres than Vietnamese is pathological language. The resemblance between pathologically distorted speech and Duras's style is difficult to overlook: nominal phrases that scarcely use adjectives, sentences with no verbs or no personal pronouns, personal pronouns with no referential solidity, and the overall arrangement of the text into small pictorial segments separated by blank spaces. Delirious female characters were present in Duras's works from very early on (Lol V. Stein and Alissa Thor being the most memorable). But it was only in the récit-théâtre that they were matched with corresponding language and form. With the political objective to destroy the character as a monadic individual, it was in this genre where Duras turned to pathological style that itself performed the kind of merging of characters introduced in Détruire, dit-elle. If we apply Jakobson's model to this style, it confirms its eccentricity; it does not fit any single category while at the same time exhibiting all aphasic symptoms. Relying neither on metaphor nor on metonymy, the récit-théâtres do not compensate for their inability to use one by using the other.

Following Duras's 1969 prognosis for her future narratives, the question remains which ultimate purpose she thought such a style served. Julia Kristeva 
posed this question in her seminal study of depression and melancholia. Analyzing the style of Duras's narratives, Kristeva wondered what Duras wished to achieve in her barren prose of "une esthétique de la maladresse" (233). She concluded that such a prose could not achieve anything because it offered nothing artistic, only an expression of suffering and unerotic ravishment. When compared to Samuel Beckett and Stéphane Mallarmé-writers Kristeva considered formally similar to Duras yet more successful in creating literary correlates to the objectless states their works invoked-Duras's stylistic awkwardness held no recuperative dimension. Beckett at least offered a refined syntax and Mallarmé an elaborate orchestration of words as remedies to the objectless states. Duras, however, offered nothing. With no redemptive value, Duras's narratives, much like the pathological speech, had no tangible meaning. This is where Kristeva, save for her critical tenor, was quite right. Although with opposite intentions, Kristeva posited the blankness of Duras's non-style as a style of its own accord. Claiming that Duras offered nothing, only silence and hollowness of meaning, put forward a description of a specific stylistic method, not unlike Beckett's refined syntax and Mallarmé's orchestration of words. In a way, Kristeva captured just what Duras announced in the interview with Rivette and Narboni, namely her vision of creating a vacuity of style with the corresponding blankness of social relations. Even though this blank style offered nothing, thus making critics and readers doubtful about its purpose and significance, generating emptiness was its firm aesthetic aspiration.

The "nothing" in Duras's style is not nothing at all, meaning a lack of something. If we take, for example, repetition, one of the principal features of this style, it is not a meaningless and circular replication, itself an indication of a psychotic breakdown or a regression into a narcissistic stage. ${ }^{3}$ As the following passage from the opening of L'Homme atlantique demonstrates, repetition has a deliberate function; it serves to de-interiorize characters:

Vous ne regarderez pas la caméra. Sauf lorsqu'on l'exigera de vous.

Vous oublierez.

Vous oublierez.

Que c'est vous, vous l'oublierez.

Je crois qu'il est possible d'y arriver.

Vous oublierez aussi que c'est la caméra. Mais surtout vous oublierez que c'est vous. Vous (7).

Instead of expressing a noncurable suffering, repetition acts as a performative call that destabilizes the self-enclosed subject. In this particular case-but one

3. For this argument, see Kristeva, ibid., and Makward 317. 
can find another example in La Maladie de la mort-this call is strengthened by the indicative mode of sentences. Resembling stage directions rather than an opening of a narrative piece, addressing the story to "vous" endows repetition with the power to solicit readers' active engagement and break the characters' encapsulation. On a rhetorical level, repetitions both heighten the presence of what is repeated and annul the meaning of the repeated phrases. The desired effect of this combination of emptying out meaning and heightening the presence of this emptiness is, in Duras, accentuated by the frequent use of the conditional and the future perfect (le futur antérieur). L'Homme assis dans le couloir, instead of opening with a declarative statement depicting a man who sits in the corridor, states that he would have been sitting there: "L'homme aurait été assis dans l'ombre du couloir face à la porte ouverte sur le dehors" (7). La Maladie de la mort creates a similarly speculative situation when from the beginning it evokes a possibility rather than describing a fact: "Vous devriez ne pas la connaître, l'avoir trouvée partout à la fois [. . .]. Vous pourriez l'avoir payée. Vous auriez dit: Il faudrait venir chaque nuit pendant plusieurs jours. Elle vous aurait [. . .]" (7-8). As Duras explains, in her stories the conditional and the future perfect are designed to undermine narrative tensions: "Quelquefois," she declares, "je dévoile le destin par le futur antérieur des événements. "Elle aurait été belle ", " elle aurait nagé loin . . . » De telle façon que le présent participe de la fin, de la mort, qu'il en soit empreint" ("Jardins d'Israël" 9).

The use of repetitions, future perfect tenses, conditionals, and the direct addressing of the reader are among the pivotal practices utilized by Duras in her hybrid stories. Devised to empty out the psychological interiority of characters and expose their blankness, the intensification of these narrative devices shows that Duras's project of the destruction of the monadic self was as alive in the early eighties as it was in the late sixties.

When in 1969 Rivette and Narboni asked Duras to compare the book and the film Détruire, dit-elle, Duras answered that they were very similar. She explained that both in her book and in her film, her goal was to liberate the characters from the rigid hierarchy of fixed perspective, a constraint she associated with the genre of the novel. By making her characters "complètement interchangeables," thus making it more difficult for the audience to separate individual characters and identify with only some of them, she believed she would change the power dynamic in the reception of the story (Destruction 48). ${ }^{4}$ In both the film and the book, the camera and the narrative voice glide inconclusively from one character to another, and, robbing the spectator and

4. For this argument see also Duras's interview in Vircondelet 162. 
the reader of a privileged point of view, put into question the very notion of the character, and arguably the reader, as self-enclosed individuals (48-49).

Despite the fact that Détruire, dit-elle refused to carve out an inner space for individual characters by constantly shifting the point of view, it nonetheless still adhered to a relatively traditional model of the character. Although metonymically dislocated along the gliding perspective that moved from one character to another, the characters in Détruire, dit-elle were still personalities with names, memories, and desires. In Duras's later narratives, these last remnants of personal identity would slowly fade away. The later characters are not only out of synch but have become nameless, often suffering from memory loss and lack of self-awareness. The récit-théâtres of the early eighties introduce characters that, deprived of any possibility of distracting themselves with mundane activities, simply spend time with each other. In these moments, when nothing happens and when even dialogues are sporadic and short, the atmosphere is one of constant weariness. Yet unlike in Alain Robbe-Grillet's novels where the same conditions push the visual aspect of the relationship between the characters to the fore, in Duras the decrease of the verbal does not bring about the increase of the visual. In both La Maladie de la mort and L'homme assis dans le couloir, the characters often do not see each other well, and their gaze and verbal exchanges lead neither to comfortable intimacy nor to secure distance. In fact, dialogues in these narratives, together with the absence of visual control, frequently end in either misunderstanding or the acknowledgement of the inability to understand one another. What is left in the story is something quite nondramatic: waiting and listening.

Reduced to waiting and listening, Duras's récit-théatres create the impression that nothing happens in them and that rather than moving forward they merely extend the emptiness and indeterminateness of the present moment. Narrative scenes in these stories often do not lead to any resolutions, and instead of progressing, as La Maladie de la mort demonstrates, they appear static:

Elle dort.

Vous éteignez les lampes.

Il fait presque clair.

Toujours c'est presque l'aube. Ce sont des heures aussi vastes que des espaces de ciel. C'est trop, le temps ne trouve plus par où passer. Le temps ne passe plus. (29-30)

Although there are moments when idleness suddenly takes on an unexpected turn to a more dynamic denouement, it is the primordial state of simplicity and exhaustion-one in which each moment remains plain and nonclimactic-that dominates these narratives. In this ascetic textual environment, characters enter 
as destitute and remain so. They do not gain depth from scene to scene. On the contrary, they are systematically robbed of everything that would render them identifiable individuals. This technique, which Leslie Hill describes as "taking away" (37), starts with very little and then takes even this little away, leaving us with only negligible action and virtually no story.

What is it that happens in the nondramatic situations of the récit-théâtres and why does Duras think it is political? Duras's answer is simple: what happens in these narratives is nothing, and that is political. As she told Rivette and Narboni in the late sixties, the new can arise only from the ashes of complete annihilation, and if literature wishes to participate in this precarious political enterprise it must follow the path of destruction. In a very anti-Sartrean way, Duras suggests that only exhausted and entirely indeterminate linguistic space holds a promise of opening a new direction for the future because it puts our understanding of personhood into question. However, the actual shape of this new direction remains vacant. It is at this juncture that many critics become uneasy. Even though the questioning Duras wishes to initiate is clear, her strategy is more difficult to decipher. Not everyone will be convinced of the political charge with which she invests blankness, for it remains unclear how exactly she envisages the new individual. Indeed, Duras's reasoning is obstinately roundabout. She claims that her works are political due to their blankness and that the questioning of their political nature shows a misunderstanding of their aesthetic and thus a misapprehension of their politics. Understanding their aesthetic, on the other hand, inevitably leads to the enactment of their political dimension. With Duras, it is as if one either complies with the logic of her aesthetics and politics or is excluded by it. But even for those who comply with it, no direct representation of the imparted political vision is provided. Faithful to the blank aesthetic, Duras's political message stays empty.

Although the emptiness of Duras's political message raises the question of its political usefulness-especially for those for whom the political entails concrete political projects and decisions-the emptiness of Duras's promise cannot be so readily used as an argument against her aesthetics. Since it is the nature of the blank aesthetic not to portray anything concrete, Duras's political imagination as expressed in her literary works must, by definition, remain empty and convey its aspirations only negatively. We already know what happens to language: fragmented syntax, brusque dialogues, generic hybridization, and pictorial organization of the text into small segments that draw attention to the whiteness of the page. But what can be said about the void of personal identity if subjectivity is what Duras believes disappears in the thoroughly exhausted literary space?

With the individual attributes, private concerns, and personal projects of the characters stripped from them, the political ideal of a new type of human 
being as expressed in the récit-théâtres implies exhaustion and an inactive type of personality. Duras's slow and weary dialogues-described by Paul Thibaud as the materialization of "une maladroite et balbutiante patience" (77)-present quiet individuals who are attentive and listening rather than active and vocal. Fulfilling her political vision, Duras's technique of narrative exhaustion and corrosion of the characters' egocentric drives posits exhaustion as a physical and mental state that fosters a more communal type of cohabitation. This cohabitation is nevertheless far from effortless. Although the exhaustion of Duras's characters is designed to activate their attentiveness-with their politeness, as Maurice Blanchot notes, verging on total selfdisregard (208) - it does not lead to tranquility and mutual understanding. In fact, Duras's characters rarely understand each other. In the exhausted space of the récit-théâtre, understanding is too much of a positively given sentiment and thus a threat to blankness. As precondition to the characters' openness to their interlocutor's absolute otherness, exhaustion does not yield anything specific, not even understanding. Since understanding runs the risk of reducing the otherness of the other person, only an exhausted and nonunderstanding self, Duras suggests, can do justice to the ethical and political imperative of a new type of selfhood. ${ }^{5}$

\section{$* * x$}

In spite of Duras's continuous emphasis on politics and the political nature of her films, plays, and literary narratives, the concerns that determined her understanding of littérature engagée were as much political as they were ethical. Already her ideals from 1968-which after Mascolo, called for radical political solidarity and, at the same time, ethical recognition of the absolute otherness of other people-show that politics did not occupy the only place in her literary project. Yet simply replacing politics with ethics does not provide a better hermeneutic tool. Duras offers neither a political position with a positively defined content nor a concretely outlined ethical stance. In the sixties and the seventies, the ethical and the political in her narratives remained oblique, and when they did come to the fore, it was only as a result of situations that, as Martin Crowley emphasized, both demanded ethical responsiveness and undermined it in the very act of calling for it (12). This politically and ethically indeterminate scenario prevailed in Duras's work in the early eighties as well. But there it was less an outcome of particular scenes and described events and more a question of style. By minimizing action and reducing stylization, Duras transferred the site of the ethical and the political

5. For the theme of failed understanding in Duras see Caruth 41-42. 
from the portrayed issues to the narrative form. In the hybrid récit-théatre, what conveyed the ethical and the political was the exhausted form and style.

Unlike the critics who have insisted on the priority of the novel and the fullness of description as catalysts of ethical issues in literary narratives, Duras proposes an ethics and politics of literature that reside essentially in form and that require a non-novelistic hybrid genre. Unlike Wayne Booth and Martha Nussbaum, for whom literature has ethical implications only when its treatment of ethical issues makes the readers follow, as Nussbaum phrases it, the "relevant activities of searching and feeling, especially feeling concerning their own possibilities as well as those of the characters" (46), Duras's récit-théatres raise ethical and political questions not in spite of the exhaustion of the positively given depiction they instigate, but because of it. After the events of May 68, form-the blank, exhausted, and minimal form-was Duras's answer to the plea for capital destruction and a vehicle for her ethical and political project. The aesthetic became the manifestation of the ethical: the exhausted story and self-effacing characters emerged as aesthetic foils to the political gesture of refusal and the ethical vision of a radical mode of intersubjectivity.

Duras's blank aesthetic did not convince everyone of its ethical and political relevance. Colin Davis, for example, has recently pointed out a disturbing impassivity in many of Duras's works with respect to their ethical considerations. Depicting scenes of violence and crime as "ordinary and banal components of human relations," Duras's stories, Davis argues, represent the kind of literature that holds no prospects for the recovery of moral values (135). Davis is certainly right to draw attention to the ethically challenging scenes in some of Duras's narratives and to call for a less facile interpretation of Duras's emphasis on writing and otherness as something that automatically qualifies as ethical and political. What complicates his criticism is Duras's understanding of the ethical and the political. Although Davis admits that art without ethics, such as Duras's, can still make ethical demands on readers by forcing them to resist the depicted values, he is not far from Nussbaum and her understanding of literary ethics. Also he accepts that ethics in literature is a depiction of particular situations that in the complexity of description implies concrete norms of behavior, enlarges our emotional repertory, and forces us to take a stance. The question is whether Duras's understanding of ethics as a refusal of concrete rules does not require a much broader, less moralistic conception of ethics.

The same question applies to the inquiries into whether Duras's ethical considerations could facilitate real political solutions. Duras would probably consent to Simon Critchley's recent words that "ethics without politics is empty, [and] politics without ethics is blind" (13), but her refusal to compromise her radical ethical vision with provisional political solutions opens her ethics to 
the allegation of an all-caring aimlessness. After all, if Duras's take on writing called for the kind of politics that refused all authority, did it not, by definition, lead to a rejection of politics as such, thereby facing the difficult task of warding off all those who accuse such a position of political ineffectuality (as for instance those who, as Kristin Ross details, explain May 68 as an unsuccessful political event because the variety of its essentially ethically motivated demands could not form a coherent politics)? If true, the only thing that Duras's political aesthetic would reveal would be the fact that the utopian ethical reform of the individual always implies an abdication of the political.

The problem with these reproaches is that in Duras, the ethical and the political cannot be limited to the understanding of politics as an implementation of concrete policies. Duras was aware of the pitfall of depoliticization to which the abdication of the political would lead, repeatedly refusing to have the ethical and the political aspects of her aesthetic project separated. She rejected the political as a defense of concrete policies and particular forms of administration, seeing in this approach an ideological notion that ruled out any radical political stance as utopian by depoliticizing it and relegating it to the sphere of ethics. For Duras, like for Jacques Rancière more recently, the aesthetic is inextricably bound with the political because it questions current distributions of the sensible into specific social groups, modes of being, and forms of communication. The aesthetic implies a certain politics without having to provide a rule that establishes their concordance. In Rancière's terms, literature is a disordering (dérèglement) of the established hierarchy-both aesthetic (normative system of representation) and political (current mode of being, ethos) because it serves to recarve (redécoupent) the established hierarchy without immediately posing a new one (Rancière 1998 and 2000).

Arguing that something new and different can come only as a result of exhaustion and emptiness, Duras sought to create an aesthetic form that refused to propose a new ethos, deliberately emphasizing its own blankness. When she explained the ideas that were behind Détruire, dit-elle to Rivette and Narboni in 1969, she promised that her minimalist approach of taking away had yet to take on a more appropriate form. She planned to invent a new type of writing that, by minimizing taxonomical restrictions of different genres and maximizing their potential to generate semantic blankness, would be a crossbreed of various genres. Her dissatisfaction with how far she would be able to push this literary destitution, however, was never to be dispelled. Even though her exploration of the récit-théâtre in the early eighties complied with her ideal of aesthetic blankness and political communality more thoroughly than any of her previous works, she was not satisfied with this narrative solution either. As she admitted at the end of her life, in a short text from 1993 cited in the opening quote, she still hoped that future narratives-not hers anymore, but someone else's-would be even more barren and epigrammatic, 
with only brief words, placed in a-grammatical sentences and leaving almost no semantic traces. While these stories would still promote her ethical vision, it is hard to say how much political weight she thought this kind of writing would be able to carry.

Bilkent University

\section{Works Cited}

Alazet, Bernard. "La Tentation du sublime." Duras Dieu et l'écrit. Actes du Colloque de l'ICP. Éd. Alain Vircondelet. Monaco: Éditions du Rocher, 1998. 85-101.

—. "Le je ne sais quoi de l'écriture." Duras, femme du siècle. Éd. Stella Harvey and Kate Ince. Amsterdam: Rodopi, 2001. 37-45.

Blanchot, Maurice. Le Livre à venir. Paris: Gallimard, 1959.

Booth, Wayne C. The Company We Keep : An Ethics of Fiction. Berkeley: U of California P, 1988.

Caruth, Cathy. Unclaimed Experience: Trauma, Narrative, and History. Baltimore: Johns Hopkins UP, 1996.

Cléder, Jean. Table ronde, 6 janvier 2002, Université Rennes 2. Marguerite Duras entre littérature et cinéma. Éd. Jean Cléder. Rennes: Ennoïa, 2003.

Critchley, Simon. Infinitely Demanding: Ethics of Commitment, Politics of Resistance. London: Verso, 2007.

Crowley, Martin. Duras, Writing and the Ethical: Making the Broken Whole. Oxford: Clarendon Press, 2000.

Davis, Colin. Ethical Issues in Twentieth-Century French Fiction: Killing the Other. London: Macmillan, 2000.

De Chalonge, Florence. "Genre, texte, sujet: quelques enjeux de l'écriture durassienne dans les annés 70." Marguerite Duras. La Tentation du poétique. Éd. Bernard Alazet. Paris: Presses Sorbonne Nouvelle, 2002. 177-88.

Duras, Marguerite. "La Destruction la parole." Cahiers du cinéma 217 (1969): 45-57.

—. Abahn Sabana David. Paris: Gallimard, 1970.

—. "Un acte contre tout pouvoir." Cinéma 223 (Juillet 1977): 48-58.

—. Le Camion. Paris: Les Éditions de Minuit, 1977.

. "Marguerite Duras explique sa vision politique." Le Quotidien de Paris. May 26, 1977.

"Les Yeux verts." Cahiers du cinéma 312-13 (1980).

—. L'Homme assis dans le couloir. Paris: Les Éditions de Minuit, 1980. . "La Voie du gai désespoir." Outside, papiers d'un jour. Paris: Albin Michel, 1981. 171-79. 
—. Agatha. Paris: Les Éditions de Minuit, 1981.

—. La Maladie de la mort. Paris: Les Éditions de Minuit, 1982.

-. L'Homme atlantique. Paris: Les Éditions de Minuit, 1982.

_. "Dans les jardins d'Israël il ne faisait jamais nuit." Cahiers du cinéma 374 (1985): 6-12.

Duras, Marguerite and Xavière Gauthier. Les Parleuses. Paris: Les Éditions de Minuit, 1974.

Hill, Leslie. Marguerite Duras: Apocalyptic Desires. New York: Routledge, 1993.

Jakobson, Roman. "Two Aspects of Language and Two Types of Aphasic Disturbances." Fundamentals of Language. Eds. Roman Jakobson and Morris Halle. The Hague: Mouton \& Co., 1956. 53-82.

Kristeva, Julia. Soleil noir: Dépression et mélancolie. Paris: Gallimard, 1987.

Makward, Christiane. "Structures du silence / du délire : Marguerite Duras / Hélène Cixous." Poétique 35 (1978): 314-24.

Mascolo, Dionys. Le Communisme: Révolution et communication, ou la dialectique des valeurs et des besoins. Paris: Gallimard, 1953.

Nussbaum, Martha. Love's Knowledge: Essays on Philosophy and Literature. Oxford: Oxford UP, 1990.

Rancière, Jacques. La Chair des mots: Politique de l'écriture. Paris: Galilée, 1998.

—. Le Partage du sensible: Esthétique et politique. Paris: La Fabrique, 2000.

Ross, Kristin. May '68 and its Afterlives. Chicago: U of Chicago P, 2002.

Thibaud, Paul. “Marguerite Duras: Les Ambiguïtés de la compassion.” Esprit 116 (1986): 75-77.

Vircondelet, Alain. Marguerite Duras ou le temps de détruire. Paris: Seghers, 1972.

Winston, Jane Bradley. Postcolonial Duras: Cultural Memory in Postwar France. Basingstoke: Palgrave, 2001. 
Copyright of Romanic Review is the property of Columbia University, Department of French \& Romance Philosophy and its content may not be copied or emailed to multiple sites or posted to a listserv without the copyright holder's express written permission. However, users may print, download, or email articles for individual use. 